\title{
Family farming and school meals in Rio Grande do Sul, Brazil
}

\author{
Fernanda Camboim Rockett ${ }^{1,2,3}$ (iD) Rafaela da Silveira Corrêa ${ }^{2,3,4}$ Gabriela Cheuiche Pires ${ }^{2,3}$ \\ Letiane de Souza Machado ${ }^{5}$ Fernanda Sonntag Hoerlle ${ }^{5}$ Camila Pinto Monteverde De Souza \\ Ana Beatriz Almeida de Oliveira ${ }^{2,3,5^{*}, 6}$ iD
}

\footnotetext{
${ }^{1}$ Programa de Pós-graduação em Ciência e Tecnologia de Alimentos (PPGCTA), Universidade Federal do Rio Grande do Sul (UFRGS), Porto Alegre, RS, Brasil.

${ }^{2}$ Centro Colaborador em Alimentação e Nutrição do Escolar (CECANE), Universidade Federal do Rio Grande do Sul (UFRGS), Porto Alegre, RS, Brasil. ${ }^{3}$ Centro de Estudos em Alimentação e Nutrição (CESAN), Hospital de Clínicas de Porto Alegre (HCPA), Universidade Federal do Rio Grande do Sul (UFRGS), Porto Alegre, RS, Brasil.

${ }^{4}$ Curso de Nutrição, Centro Universitário Ritter dos Reis (UniRitter), Porto Alegre, RS, Brasil.

${ }^{5}$ Curso de Nutrição, Departamento de Nutrição, Faculdade de Medicina, Universidade Federal do Rio Grande do Sul (UFRGS), Porto Alegre, RS, Brasil, 90040-060. E-mail: ana.beatriz@ufrgs.br. "Corresponding author.

${ }^{6}$ Programa de Pós-graduação em Alimentação, Nutrição e Saúde (PPGANS), Universidade Federal do Rio Grande do Sul (UFRGS), Porto Alegre, RS, Brasil.
}

\begin{abstract}
In Brazil, at least 30\% of the total financial resources provided by the federal government for school feeding should be used to buy products from family farming. The present study examines the profile of the purchase of these products in municipalities of the state of Rio Grande do Sul (RS), south Brazil, in 2014. A cross-sectional descriptive study was carried out with information obtained through a questionnaire sent to the municipalities and filled by respondents. Of the 371 participating municipalities, 367 acquired products from family farming, and $86.8 \%$ of these municipalities achieved the minimum percentage required. Nutritionists and farmers were the main components involved in the articulation of this process. Difficulties faced by these individuals included the lack of organization of the producers, failure to meet the demand, and lack of interest. More than $80 \%$ of the municipalities bought food from the "Vegetables", "Cereals, Breads, Pasta, and Tubers" and "Fruits" groups. Only 8\% purchased products from socio-biodiversity. There was a great diversity of food purchased, most of which were in natura, despite the low acquisition of socio-biodiversity products. Results of this study indicated the concern and tendency of the Brazilian municipalities to support the local economy with incentives to consumption and production of regional foods.
\end{abstract}

Key words: school meals, food and nutrition security, agriculture, public policy.

Agricultura familiar e alimentação escolar no estado do Rio Grande do Sul, Brasil

RESUMO: No Brasil, no mínimo 30\% do total dos recursos financeiros repassados pelo governo federal para a alimentação escolar devem ser utilizados na compra de produtos da agricultura familiar. Este estudo analisa o perfil da aquisição desses produtos em municipios do Rio Grande do Sul (RS), em 2014. Foi realizado estudo transversal descritivo com informações obtidas de um questionário encaminhado aos municipios. Dos 371 municipios participantes, 367 adquiriram produtos da agricultura familiar, sendo que 86,8\% deles atingiram o percentual mínimo exigido. Os nutricionistas e os agricultores foram os principais envolvidos na articulação do processo e, dentre as dificuldades enfrentadas estão a falta de organização dos produtores, a impossibilidade de cumprirem com a demanda e o desinteresse. Mais de $80 \%$ dos municípios compraram dos grupos "Hortaliças, legumes e verduras", "Cereais, pães, massas e tubérculos" e "Frutas", embora apenas 8\% adquiriam produtos da sociobiodiversidade. Verificou-se uma grande diversidade de alimentos adquiridos, sendo a maior parte produtos in natura, apesar da baixa aquisição de produtos da sociobiodiversidade. Os resultados indicam a tendência dos municípios em fomentar a economia local, com incentivo ao consumo e produção de alimentos regionais.

Palavras-chave: refeições escolares, segurança alimentar e nutricional, agricultura, políticas públicas.

\section{INTRODUCTION}

Law No. 11,326 of July 24, 2006 establishes the guidelines for the formulation of the National Policy of Family Farming and Rural Family Enterprise. According to this law, a family farmer is the one who practices activities in rural areas, does not have a property greater than 4 fiscal modules, has the family as the predominant labor force in economic activities, a minimum percentage of income originated from the economic activities of their establishment/enterprise, and directs the establishment/enterprise with their family (BRASIL, 2006). Silviculture workers, fish farmers, extractivists, fishermen, natives, and quilombolas are also included in this category (BRASIL, 2006). 
In contrast to agribusiness, family farming is based on small family farm ownership, ecological, economic, social, cultural, political, and ethical sustainability (MACHADO et al., 2018). Nearly 70 percent of the staple food consumed by Brazilians is produced by family farming. Therefore, it is considered the main food producer for the countryside and the city as well, and plays a central role in the fight against hunger and in food and nutrition security in Brazil (SERENINI, 2015). With the emergence of public policies aiming family farming, there was a greater involvement in the internal market of products and foods originated from it as well as greater income generation for families living in the countryside (BRASIL, 2014).

In 2009, Law No. 11,947 was published in Brazil. Hence, a regulatory framework was established in the National School Feeding Program (PNAE). According to its guidelines, food should be adequate, healthy, diverse, and safe, and culture, traditions, and eating habits should be respected (BRASIL, 2009; TEO; MONTEIRO, 2012). In addition, it stimulated support for sustainable development with the incentive to purchase diversified food products which were locally produced preferably by family farming (BRASIL, 2009). Based on this legislation, it was determined that at least $30 \%$ of all the resources passed through the National Fund for Education Development (FNDE) for the States, Municipalities, and Federal District should be used to purchase family farming genres (BRASIL, 2009). Subsequently, this purchase process was regulated by Resolution CD/FNDE No. 04, of April 2, 2015 (BRASIL, 2015).

As a result, the institutional purchase of family farming was facilitated and the procedures of this process were simplified through a Public Call (BRASIL, 2009; BRASIL, 2015). Acquisition of products from family farming has become part of a policy that recognizes the need to produce food that meets the nutritional demands of the population and also guarantees the economic and social growth of the family producer including the creation of short production and marketing chains (AGUIAR et al., 2018). Such policy brings the producer and the consumer close to one another, strengthens social relationships, and values productive diversity (BRASIL, 2016a).

As a partnership with family farming was established, the program promoted a major transformation in school meals as it allowed varied, healthy and fresh foods to be consumed daily by students from public schools (BRASIL, 2016a;
TRICHES; SCHNEIDER, 2010) resulting in changes in food consumption (TRICHES; SCHNEIDER, 2010). The acquisition of these food items also led to retention of the capital spent by the municipalities within the region itself which strengthened the local economy. For family farmers, the PNAE became an important sales venue and generated regular income contributing to job creation in the rural areas (BRASIL, 2016a, TURPIN, 2009). In addition, it strengthened intersectoriality (TOYOYOSHI et al., 2013) promoting discussions about healthier and unconventional types of food production/consumption and also the importance of this process to the environment and to economy (BRASIL, 2016a).

Despite the numerous economic, social and health benefits of this process (WORLD FOOD PROGRAM, 2013), it is known that Brazilian municipalities still face difficulties in complying with the legislation (FERIGOLLO et al., 2017). Few comprehensive, thorough studies have analyzed their implementation. Considering that municipalities still deal with these problems even after a few years that the law that establishes a minimum percentage of purchase was published (BRASIL, 2009), the detailed characterization of this process is of extreme relevance. Studies that allows us to monitor law compliance is encouraged (BACCARIN et al., 2017; FERIGOLLO et al., 2017). Thus, the present study aimed to analyze the profile of the purchases of family farming products for school meals in municipalities located in Rio Grande do Sul (RS), south Brazil, in 2014.

\section{MATERIALS AND METHODS}

The present study was carried out in Rio Grande do Sul (RS), a Brazilian federal unit located in the southern region of the country which is divided into 497 municipalities. Its total area is $281,730,223 \mathrm{~km}^{2}$. It has a total of approximately 10 million and 700 thousand citizens according to the 2010 Census (IBGE, 2010). This is a cross-sectional study with data collected between August 2015 and October 2015 by using an online questionnaire (Survey Monkey ${ }^{\circledR}$ platform) which was emailed to the Municipal Department of Education from all municipalities of Rio Grande do Sul $(n=497)$ along with a cover letter introducing our research to the responders. The invitation was sent to representatives from this department who actively participated in the process of buying family farming food items (Secretary of Education, nutrition technician assigned, staff technical nutritionist, school nutrition coordinator 
or municipal management representative). We had to resend the questionnaire for all those who had not returned to the initial request. These individuals were also contacted by phone for any clarification and acknowledgement of receipt of the set of questions for our survey. As participants accepted to take part in the research study, the return of the completed questionnaire was used and the municipalities that declined to participate were not contacted again.

The questionnaire included 35 questions related to the purchase of family farm food items that were prepared based on the current legislation (BRASIL, 2009; BRASIL, 2013; BRASIL, 2015). Of these, 30 questions were selected for the present study including identification and contact data, resource management methods, if a family farm food item was purchased or not in 2014, percentage of acquisition of food items from family farming for school meals achieved by municipalities in 2014, criteria considered in the preparation of food menus, purchasing methods, criteria for selection and prioritization of proposals, social actors involved in the articulation of the process and formation of the same, financial resources used, challenges and obstacles faced, products acquired and interest in acquisition of new products, purchases origin, replacement of products, delivery options, sociobiodiversity products (native species of Brazilian flora described in Interministerial Ordinance No. 163/2016) (BRASIL, 2016b), among other issues.

According to the Brazilian Institute of Geography and Statistics (IBGE), 497 municipalities were divided into 7 mesoregions as follows: Northeast Rio Grande do Sul ( $\mathrm{n}=54)$, Northwest Rio Grande do Sul ( $\mathrm{n}=217)$, Western center Rio Grande do Sul $(\mathrm{n}=31)$, Eastern center Rio Grande do Sul $(n=54)$, Metropolitan Region of Porto Alegre $(n=98)$, Southwest Rio Grande do Sul $(\mathrm{N}=17)$, and Southeast Rio Grande do Sul (n=26) (IBGE, 2010).

In order to analyze which products from family farming were purchased by the municipalities, food items were divided into the following groups: vegetables; fruits; drinks; cereals, breads, pastas and tubers; meat, fish, and eggs; milk and derivatives (yoghurt, milk drinks, cheese, etc.); legumes (beans, lentils, chickpeas, soybeans, etc.); fats and oils (lard, olive oil, etc.); sugar and candies; or other food items.

All data were tabulated using the Excel $^{\circledR}$ Software version 2016 and analyzed in the Software Statistical Package for the Social Sciences version 19 with descriptive analyses in absolute and relative frequencies, mean and standard deviation.
The research proposal was approved by the Research Committee of the Faculty of Medicine of the Federal University of Rio Grande do Sul (UFRGS), Porto Alegre, RS, Brazil (Protocol No. 27815).

\section{RESULTS}

Of the 497 municipalities located in the State of Rio Grande do Sul, south Brazil, 371 participated in this survey which corresponds to $74.6 \%$ of the total number of municipalities in this state.

Regarding geographic distribution, the mesoregion with the highest number of responses was the Northwest Rio Grande do Sul with $43.9 \%$ $(n=163)$ followed by the Metropolitan Region of Porto Alegre with $18.9 \%(n=70)$. This is due to the fact that these are the mesoregions with the largest number of municipalities - 217 and 98, respectively. Similarly, the mesoregions with the lowest number of responses - $2.7 \% \quad(n=10)$ from the Southwest Rio Grande do Sul and 5.4\% $(n=20)$ from the Western Center Rio Grande do Sul - are the mesoregions with the lowest number of municipalities - 17 and 31, respectively. Comparing the number of respondents with the total number of municipalities covered in each of the mesoregions, there was a response rate above $58.8 \%$ in all mesoregions.

The majority of the respondents were dedicated nutrition technicians or nutritionists belonging to technical staff $(n=317,85.4 \%)$ followed by Secretaries of Education $(n=32,8.6 \%)$ and other positions $(n=22,5.9 \%)$ such as agents/assistants or administrative advisors, members of the School Feeding Council (CAE), Pedagogical and School feeding Coordintors, etc.

Data on the purchase of family farm products for school meals are presented in table 1 . Of the total number of participating municipalities, most of them had a centralized resource management center $(n=360 ; 97.0 \%)$; i.e., the municipality received federal funds from FNDE, purchased food products, and then distributed them to the schools from the municipality. When creating the food menu, more than half of the survey participants considered local eating habits, seasonality, local/regional availability, and the price of the products.

The process of purchasing food items from family farms was carried out in 2014 by most of the responding municipalities ( $\mathrm{n}=367,98.9 \%$ ). Problems with documentation such as failure to issue an invoice and unsatisfactory hygienic-sanitary conditions were 
the reasons cited by $4(1.1 \%)$ municipalities for not purchasing food items from family farms. Producers unwilling to provide food items for the PNAE $(\mathrm{n}=2 ; 50.0 \%)$ was the reason cited by $1(25.0 \%)$ municipality for not ordering products from family farms. One of the municipalities did not specify why purchases were not made.

Of the municipalities that purchased products from family farming, the cited procedures were public call $(\mathrm{n}=358,97.5 \%)$ and/or bidding $(n=19,5.2 \%)$. Most of the municipalities used federal resources for the PNAE of the FNDE ( $\mathrm{n}=358,97.5 \%$ ) and only 136 (37.1\%) municipalities completed the purchase using the Executing Entity's own funds.

Not all municipalities were able to report the percentage of purchases of products from family farming to school meals achieved in 2014. A total of 357 valid answers was received. Although, most of these municipalities reached the minimum value recommended by the legislation of $30 \%$ of the total of federal resources provided to them, it is worth mentioning that $47(13.2 \%)$ of these municipalities still did not comply with relevant regulation even after 5 years that such policy was established. Of those who were able to comply with the legislation $(n=310,86.8 \%)$, the average percentage of acquisition of food items from family farming was $47.9 \pm 19.3 \%$. In addition, in the case of those municipalities that meet the minimum required but do not reach $100 \%$ when classified in intermediate bands, the majority $(n=197 ; 55.2 \%)$ still acquire less than $50 \%$ of the total resources.

In the purchase process, the prioritization of the proposals was based on the criteria described in the current legislation $(\mathrm{n}=239,65.1 \%)$; although, $121(33.0 \%)$ municipalities still mentioned that they considered the lowest price as the criterion used in the bidding process. Six $(1.6 \%)$ municipalities did not answer this question and $1(0.3 \%)$ said that both criteria were used. The presence of priority groups such as agrarian reform settlements, indigenous traditional communities or quilombola communities that produce food was mentioned by 49 (13.2\%) municipalities of which $34(69.4 \%)$ prioritized these groups in the acquisition process (choice of supplier). Fourteen of the 15 municipalities that did not prioritize any group mentioned that producers: a) showed no interest in participating $(n=7) ; b)$ they were not yet organized to participate in the process $(\mathrm{n}=5)$; c) they did not have sufficient production to supply the demand $(n=2)$.

When questioned about the entities/organs/ individuals who participated in the arrangement of the purchase of family farming in 2014 (Table 1), on average $5 \pm 2$ entities/organs/individuals participated in this process. In particular, the nutrition technician assigned and the Family Farmers and their organizations (Associations and Cooperatives) had greater participation in the process. The Municipal Council of Rural Development (CMDR) and the Municipal Council for Food Security (COMSEA) were the least mentioned by respondents.

The challenges/obstacles or difficulties for the acquisition of food from Family farming are presented in table 1 . The main ones pointed out by the municipalities were that the Family Farmers are, to a certain extent, poorly organized. This is due to the fact that they fail to meet the demand with regard to the amount as well as the variety of products needed $(52.8 \%, \mathrm{n}=196)$.

Table 2 shows the main products of family farming acquired by the municipalities divided into 9 food groups. For the 363 municipalities with valid answers to this question, the average acquisition was 19 products per municipality. Items classified in the group "vegetables" were the most acquired $(92.3 \%$ of the municipalities bought these products) followed by "cereals, breads, pastas, and tubers" $(92.0 \%)$, and "fruits" $(84.0 \%)$. The group with the lowest acquisition was "oils and fats" with only $14.3 \%$ of the municipalities purchasing these products. Other items cited by the municipalities but not included in any food group were: sauce or tomato extract $(6.6 \%)$, peanut $(3.0 \%)$, and vinegar $(0.8 \%)$. As for the variety of products, the group of "vegetables" was also the one that presented the largest number of items - 38 foods cited by participants.

Municipalities that did not purchase any products of animal origin from family farming due to the lack of sanitary inspection $(n=155)$ mentioned the following products with such problem: eggs (n $=126,81.3 \%)$, meat $(\mathrm{n}=96,61.9 \%)$, milk and its derivatives $(n=74,47.7 \%)$, honey $(n=7 ; 4.5 \%)$, and lard $(\mathrm{n}=1,0.6 \%)$

A total of 363 answers on the interest in acquiring family farming products that still cannot be obtained due to unavailability were received. For $82(22.6 \%)$ municipalities all the necessary products are already acquired. For the other municipalities, the main demands are related to animal products - meat, fish, and eggs $(n=162,57.7 \%)$ and dairy products $(\mathrm{n}=98,34.9 \%)$ - and a wide variety of fruits $(\mathrm{n}=118,42.0 \%)$.

Questions about the origin of the purchases of products from family farming for school meals in 
Table 1 - Data on the purchase of family farming products for school meals in the municipalities of Rio Grande do Sul, south Brazil.

\begin{tabular}{|c|c|c|}
\hline & $\mathrm{n}$ & $\%$ \\
\hline \multicolumn{3}{|l|}{$\%$ acquisition of family farming products for school meals achieved in $2014(\mathrm{n}=357)$} \\
\hline $0 \%$ & 6 & 1.7 \\
\hline between $1.0 \%$ and $29.9 \%$ & 41 & 11.5 \\
\hline between $30.0 \%$ and $99.9 \%$ & 301 & 84.3 \\
\hline between $30.0 \%$ and $49.9 \%$ & 197 & 55.2 \\
\hline between $50.0 \%$ and $99.9 \%$ & 104 & 29.1 \\
\hline $100.0 \%$ & 9 & 2.5 \\
\hline \multicolumn{3}{|l|}{ Type of management of the PNAE resources $(n=371)$} \\
\hline Centralized (the city acquires the products and distributes them to schools) & 360 & 97.0 \\
\hline Mixed (City hall buys part of the food and distributes it and schools purchase the other part - mainly perishable food items) & 6 & 1.6 \\
\hline School based (each school buys food products) & 3 & 0.8 \\
\hline Outsourced (company is hired to manage school purchases and meals) & 2 & 0.5 \\
\hline 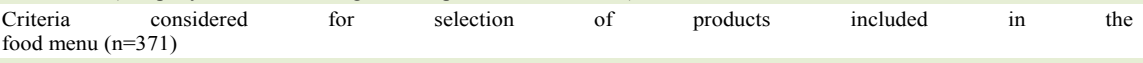 & & \\
\hline Respect for local eating habits & 358 & 96.5 \\
\hline Seasonality of production & 304 & 81.9 \\
\hline Map of local/regional production & 250 & 67.4 \\
\hline Product Prices & 203 & 54.7 \\
\hline Others (acceptability, culture, availability and amount of products, nutritional requirements, etc.) & 26 & 7.0 \\
\hline \multicolumn{3}{|l|}{ Entities/organs/individuals that participated in the articulation of the purchase of family farming in 2014 ( $n=367)$} \\
\hline Nutrition Technician responsible for the PNAE & 320 & 87.2 \\
\hline Family Farmers & 284 & 77.4 \\
\hline Secretary of Education & 281 & 76.6 \\
\hline EMATER or other agency of Technical Assistance and Rural Extension & 267 & 72.8 \\
\hline Purchasing/Finances/Bidding Department & 249 & 67.8 \\
\hline CAE & 228 & 62.1 \\
\hline Associations and Cooperatives & 188 & 51.2 \\
\hline Union of Rural Workers or Family Farmers & 70 & 19.1 \\
\hline Staff Nutrition Technician & 63 & 17.2 \\
\hline Department of Health (health surveillance) & 48 & 13.1 \\
\hline Secretariat of Agriculture or similar & 15 & 4.1 \\
\hline COMSEA & 7 & 1.9 \\
\hline CMDR or similar & 5 & 1.4 \\
\hline \multicolumn{3}{|l|}{ Challenges/Obstacles/Difficulties for the purchase of family farming food items $(\mathrm{n}=371)$} \\
\hline The production of family farming is unable to meet the demand - in relation to the amount and/or variety required & 196 & 52.8 \\
\hline Family farmers' lack of interest & 168 & 45.3 \\
\hline $\begin{array}{l}\text { Family Farmers are not well-organized - Examples: lack of documentation, products with inadequate hygienic-sanitary } \\
\text { conditions or do not issue invoice }\end{array}$ & 133 & 35.8 \\
\hline Absence of Family Farmers in the Municipality & 130 & 35.0 \\
\hline Difficulty of logistics in distribution & 101 & 27.2 \\
\hline Lack of training of the individuals involved in the acquisition process & 52 & 14.0 \\
\hline Articulation/Communication between the Secretariat of Education and Family Farmers & 47 & 12.9 \\
\hline Distrust of family farming in marketing to the Executing Agency/City Hall & 40 & 10.8 \\
\hline Lack of knowledge or doubts regarding current legislation & 38 & 10.2 \\
\hline Inadequate school structure and/or insufficient human resources & 20 & 5.4 \\
\hline \multicolumn{3}{|l|}{ Type of supplier $(\mathrm{n}=367)$} \\
\hline Cooperatives & 223 & 60.8 \\
\hline Individual producers (not organized in groups) & 202 & 55.0 \\
\hline Individual producers organized in informal groups (variousfarmers participate in the same sales project) & 117 & 31.9 \\
\hline Associations & 53 & 14.4 \\
\hline \multicolumn{3}{|l|}{ Location of suppliers $(n=367)$} \\
\hline Same municipality & 336 & 91.6 \\
\hline Other municipalities close to the region & 200 & 54.5 \\
\hline Other municipalities in the state to which it belongs & 54 & 14.7 \\
\hline Rural territory to which it belongs & 47 & 12.8 \\
\hline Other states & 1 & 0.3 \\
\hline \multicolumn{3}{|l|}{ Form of delivery of products purchased $(n=367)$} \\
\hline Suppliers deliver food items directly at schools & 214 & 58.3 \\
\hline Suppliers deliver food items to the central warehouse and the Executing Agency distributes these food items & 205 & 55.9 \\
\hline Executing Entity searches the products on the properties and distributed the food items & 44 & 12.0 \\
\hline \multicolumn{3}{|l|}{ Participants in the training of the individuals involved in the process of acquiring food items from family farming $(\mathrm{n}=290)$} \\
\hline Nutritionist & 259 & 89.3 \\
\hline School Meal Counselors & 177 & 61.0 \\
\hline Food Handlers & 144 & 49.7 \\
\hline Purchasing/Bidding Section & 140 & 48.3 \\
\hline Farmers & 131 & 45.2 \\
\hline EMATER or other agency of Technical Assistance and Rural Extension & 10 & 3.4 \\
\hline Others (head of school, individual responsible for school feeding, etc.) & 9 & 3.1 \\
\hline
\end{tabular}

Others (head of school, individual responsible for school feeding, etc.)

EMATER=Enterprise of Technical Assistance and Rural Extension; PNAE = National School Feeding Program.

Ciência Rural, v.49, n.2, 2019. 
the municipalities (type of supplier and location of the supplier) were also included in the questionnaire. Table 1 shows that, in most municipalities, the supply was made through Cooperatives (60.8\%) and individual producers that did not belong to any group $(55.0 \%)$. Regarding the location of suppliers and municipality from where food items are being purchased, the majority purchase these items from producers in the same city $(91.6 \%)$ or from other cities nearby in the same region $(54.5 \%)$. Only 1 municipality mentioned the purchase of products from out-of-state farmers. In most municipalities, products were delivered at schools directly by the producers $(\mathrm{n}=214,58.3 \%)$.

In purchases made in 2014, 58 (15.8\%) municipalities reported that in some cases during the term of the contracts products had to be replaced. The most cited reasons for such change as described by 54 municipalities included difficulties in production (delay, unfavorable climatic conditions,

Table 2 - Family farming products purchased by the municipalities of Rio Grande do Sul, south Brazil, for school meals in 2014 ( $\mathrm{n}=363$ ).

\begin{tabular}{|c|c|c|c|c|}
\hline Food groups & $\mathrm{n}$ & $\%$ & $\begin{array}{l}\text { Average of } \\
\text { products } \\
\text { purchased by } \\
\text { municipality }\end{array}$ & $\begin{array}{l}\text { Products marketed and percentage of municipalities that purchased } \\
\text { products }\end{array}$ \\
\hline Vegetables & 335 & 92.3 & 9 & $\begin{array}{c}38 \text { items: Lettuce }(79.3 \%) \text {, Cabbage }(70.0 \%) \text {, Carrot }(68.3 \%) \text {, Beetroot } \\
(67.8 \%) \text {, Broccoli }(57.9 \%) \text {, Cauliflower }(49.0 \%) \text {, Parsley and chive } \\
(46.3 \%) \text {, Pumpkins }(46.6 \%) \text { Tomato }(41.6 \%) \text {, Cabbage }(41.0 \%) \text {, Onion } \\
(39.1 \%) \text {, Garlic }(28.9 \%) \text {, Chuchu }(26.4 \%) \text {, Spinach }(18.2 \%) \text {, Pod }(16.3 \%) \text {, } \\
\text { Pepper }(14.6 \%) \text {, Arugula }(12.9 \%) \text {, cucumber } \text { in natura or conserved } \\
(12.9 \%) \text {, zucchini }(11.0 \%) \text { and Chinese Cabbage }(10.5 \%) \text {. Radish, Purple } \\
\text { Cabbage, Parsley, Mustard, Spring onion, Chicory, Watercress, Eggplant, } \\
\text { Turnip, Chard, Garnish, Beet, Radite, Bay, Basil, Marjoram, Okra, and } \\
\text { Salvia }(<10 \%) .\end{array}$ \\
\hline $\begin{array}{l}\text { Cereals, breads, } \\
\text { pastas, and } \\
\text { tubers }\end{array}$ & 334 & 92.0 & 4 & $\begin{array}{c}22 \text { items: Cassava }(57.3 \%) \text {, Sweet potato }(51.2 \%) \text {, Biscuits/Cookies } \\
(46.8 \%), \text { Various breads }(37.2 \%) \text {, Pasta/Noodles }(25.1 \%) \text {, Potato }(24.2 \%) \text {, } \\
\text { Rice }(15.4 \%) \text { and Corn }(15.2 \%) \text {. Corn flour, Wheat flour, Popcorn corn, } \\
\text { Cakes, Hominy, Pizza, Esfiha, Baked/whole pastry, Lasagne, Corn } \\
\text { Quirera, Oats, Cassava starch, and Yacon }(<10 \%) .\end{array}$ \\
\hline Fruits & 305 & 84.0 & 4 & $\begin{array}{c}29 \text { items: Orange }(71.9 \%) \text {, Bergamot orange }(54.3 \%) \text {, Strawberry }(25.3 \%) \text {, } \\
\text { Banana }(19.0 \%) \text {, Peach }(15.2 \%) \text {, Persimmon }(14.6 \%) \text {, Lemon }(14.0 \%) \text {, and } \\
\text { Apple (13.5\%). Watermelon, Melon, Grape, Avocado, Papaya, Kiwi, } \\
\text { Pineapple, Fruit pulps, Guava, Mango, Pear, Blackberry, Passion fruit, } \\
\text { Plum, Star fruit, Jaboticaba, Acerola, Raspberry, Lime, Bilberry, and } \\
\text { Nectarine }(<10 \%) .\end{array}$ \\
\hline Legumes & 219 & 60.3 & 1 & $\begin{array}{c}5 \text { items: Beans }(59.5 \%) \text {, Peas }(4.7 \%) \text {, Lentils }(2.8 \%) \text {, Fava Beans }(0.6 \%) \text {, } \\
\text { and Soybeans }(0.3 \%) .\end{array}$ \\
\hline $\begin{array}{l}\text { Milk and } \\
\text { dairy products }\end{array}$ & 205 & 56.5 & 2 & $\begin{array}{c}7 \text { items: Milk (34.7\%), Dairy drinks }(28.1 \%) \text {, Cheese }(22.9 \%) \text {, Milk } \\
\text { powder }(16.0 \%) \text {, and Yogurt }(7.7 \%) \text {. Cottage cheese }(2.5 \%) \text { and chocolate } \\
(0.6 \%) .\end{array}$ \\
\hline $\begin{array}{l}\text { Sugar and } \\
\text { candies }\end{array}$ & 196 & 54.0 & 2 & $\begin{array}{c}10 \text { items: Chimia/Fruit jelly }(17.1 \%) \text {, Honey }(17.1 \%) \text {, Sweet milk }(14.9 \%) \text {, } \\
\text { Cane molasses }(13.5 \%) \text {, Fruit candy/pumpkin }(13.2 \%) \text {, Brown sugar } \\
(12.9 \%) \text {, Refined sugar }(0.8 \%) \text {, "Rapadura" }(0.8 \%) \text {, Sweets in syrup and } \\
\text { Condensed Milk }(0.3 \%) .\end{array}$ \\
\hline $\begin{array}{l}\text { Meat, fish, and } \\
\text { eggs }\end{array}$ & 194 & 53.4 & 2 & $\begin{array}{c}14 \text { items: Chicken }(23.7 \%) \text {, Chicken Eggs/Quail eggs }(21.8 \%) \text {, Beef } \\
\text { (15.2\%), Pork (14.6\%), Sausage }(4.3 \%) \text {, Fish }(4.1 \%) \text {, Chicken liver/cattle } \\
\text { liver }(3.0 \%) \text {, Mortadella }(3.0 \%) \text {, Ham/ham based food }(3.0 \%) \text {, Salami } \\
(1.1 \%) \text {, chicken heart and gizzard }(0.8 \%) .\end{array}$ \\
\hline Drinks & 166 & 45.7 & 1 & $\begin{array}{c}11 \text { items: Grape Juice }(36.8 \%) \text {, Orange Juice }(6.3 \%) \text {, Fruit Juice - } \\
\text { unspecified flavor }(6.3 \%) \text {, Peach Juice }(1.9 \%) \text { and concentrated juice in } \\
\text { general }(1.7 \%) \text {. Nectars in general and bergamot, blackberry, apple, } \\
\text { passion fruit and strawberry juices }(<0.6 \%) \text {. }\end{array}$ \\
\hline Fats and oils & 52 & 14.3 & 1 & 3 items: Soybean oil (8.5\%), Milk Cream (3.0\%) and Sour Cream (2.8\%). \\
\hline
\end{tabular}


insufficient amount to meet the demand, etc.) $(\mathrm{n}=43,79.6 \%)$ followed by nonconformities of the products (suboptimal, insufficient, or poor quality, deterioration, etc.) $(n=7 ; 13.0 \%)$. Another reason cited by survey participants was the low acceptability of the food items by students $(n=4,7.4 \%)$,

Regarding the acquisition of sociobiodiversity products, 362 municipalities answered the questions. Of these, $333(92.0 \%)$ do not buy any product. Of the 29 that bought products, $21(72.4 \%)$ mentioned pinhão (pine nut), $2(6.9 \%)$ mentioned juçara and maracujá do mato (passion fruit), 1 (3.4\%) mentioned pitanga (Brazilian cherry) and Araçá (Cattley guava), 2 (6.9\%) mentioned jabuticaba (Brazilian grape tree), 1 (3.4\%) mentioned açaí juçara, $1(3.4 \%)$ mentioned maracujá do mato, and 1 (3.4\%) mentioned goiaba serrana (feijoa).

With regard to the possibility of including these products in school meals of the municipality, participants considered such possibility in 214 $(59.3 \%)$ of the 361 valid answers.

For those who answered positively about the inclusion of socio-biodiversity products in school meals, 37 (17.3\%) did not elaborate on what it took to make it effective. The other respondents mentioned the following as necessary to include such products in school meals: a) Identify farmers interested in producing and marketing, training these individuals to do so, encouraging the production and distribution logistics or that these farmers regularize the documentation required for the process - adequate hygienic-sanitary conditions, producer invoice, etc. $(\mathrm{n}=145,67.8 \%) ; \mathrm{b})$ Aware and educate the population about the importance of these products, stimulate consumption or carry out Food and Nutrition Education activities to improve the acceptance of these food items ( $\mathrm{n}=27 ; 12.6 \%)$; $)$ Increased support and investment by managers or greater mobilization/ articulation of social actors involved in the process $(\mathrm{n}=16,7.5 \%)$; d) Adapt the food menu, organize meetings (seminars, conferences) or cooking workshops on meal preparation and organize handling logistics (eg, peeling pinhão) $(\mathrm{n}=15 ; 7.0 \%)$; e) That food items are sold at affordable prices $(n=10,4.7 \%)$ and; f) To do more research on these products or to disclose the legal requirements for their purchase $(n=3 ; 1.4 \%)$.

Many municipalities mentioned that some of the listed products were already included or would be included in the purchasing processes in years to come. The following are the food items that municipalities mentioned that would possibly be included in the purchasing processes in the near future: pinhão $(n=36)$, jabuticaba $(n=5)$, pitanga/ goiaba serrana/passion fruit $(\mathrm{n}=4)$, araçá/uvaia $(\mathrm{n}=2)$, butiá $(\mathrm{n}=2)$, açaí juçara/araticum/fisális/guabiroba $(\mathrm{n}=1)$. Of those who responded negatively, $8(5.4 \%)$ did not explain why they gave such answer. For those who mentioned the reason, the following were cited: a) there is/are no production/suppliers to these products in the city or nearby and also due to the fact that the existing production is insufficient to meet the demand $(n=105 ; 71.4 \%) ; b)$ due to the difficulty in acceptance of these products by students at elementary school since they were not familiar with the food items or these food items were not part of the local habits or culture $(n=46 ; 31.3 \%)$; $)$ due to the high cost of these food items $(n=8 ; 5.4 \%)$; $)$ because these products are very perishable, difficult to distribute/store/handle at schools $(n=3,2.0 \%)$; and e) due to the fact that students were already consuming these products at home or these items were already being produced at the school gardens for local consumption and; therefore, there was no need to purchase them $(n=3,2.0 \%)$. Despite the negative responses, 2 municipalities indicated that the pinhão would be a product that would probably be included in school meals.

In the analysis of the percentage of formation of actors involved in the process of acquisition of food genres from agriculture farming (Table 1), 72 municipalities responded that no training was carried out and 9 did not answered these questions. Of 290 participants $(78.2 \%)$ who responded positively, we noticed that on average $2 \pm 1$ individuals had training in this process. The nutritionist, the members of the $\mathrm{CAE}$, and food handlers were the individuals mainly involved in this process.

\section{DISCUSSION}

In the present study, the sample size stands out as a significant percentage of municipalities was covered in this survey. In addition, there was good representation between different mesoregions with direct data retrieval. This may significantly and credibly reflects the reality of the actual process of acquisition of food items from family farming for school meals in the state of Rio Grande do Sul, south Brazil.

In the study conducted by BELIK \& CHAIM (2009), researchers reported that most municipalities had centralized management. Similarly, in our study we reported $97 \%$ of municipalities with this type of management. A great advantage of the centralized type of management is the ability to 
perform an effective control of the entire process and ensure that product quality is applied to all schools in the municipality. In addition, centralization provides best trade and articulation of the City Hall with regard to farmers and cooperatives. In the present survey, we observed that the majority of the municipalities fulfilled the requirement of targeting at least $30 \%$ of the resources from the FNDE for school meals to food family farming. Besides, the mean percentage of acquisition is above the minimum required. When data of the municipalities that meet the legislation are stratified in intermediate levels of percentage of purchases achieved, it is noted that incentives are still necessary as only $31.6 \%$ of the municipalities consistently overcome the minimum required by law ( $>50 \%$ ). According to RIBEIRO et al. (2013), law enforcement contributes to a better development of the regions favoring field workers, creating more jobs, and generating more income to families. In addition, it improves food and life quality of students. In comparison with other regions in Brazil, studies carried out by SARAIVA et al. (2013) and SOARES et al. (2013) described that the Southern region of the country had the highest percentage of acquisition ( $71.3 \%$ and $87.0 \%$ in 2010 and 2012, respectively). These results are possibly related to the level of organization of farmers and managers. FERIGOLLO et al. (2017) analyzed public calls from a small number of municipalities in RS and reported that $71.2 \%$ of these municipalities achieved the minimum percentage required in 2013. In one study in which 7 publications on the subject were reviewed, it was concluded that participation of municipalities in this process is still poor and limited (PEDRAZA et al., 2018). Our findings are in contrast to the findings of PEDRAZA et al., (2018). It should be emphasized that $2.5 \%$ of the municipalities allocated all the resources provided by the FNDE to the purchase of food items from family farming. This percentage is low but still shows a major breakthrough of the PNAE and demonstrates that such percentage can be achieved regardless of the volume of resources and size of the municipality. In addition, dissemination of these municipalities by the responsible bodies may encourage that more of these successful experiences are sought after and repeated. Such scenario promotes an understanding of the process that led to these results. Process of organization by which they were subjected is important for the implementation and maintenance of the public policy in the country.

Nevertheless, it should be emphasized that a significant percentage still does not fulfill the legislation requirement to achieve the $30 \%$ proposed by lawmakers. In addition, some municipalities use the lowest price offer as a criteria for the selection of proposals. In this context, the FNDE which is the agency responsible for coordinating the PNAE has a crucial role in order to guarantee that obligations determined by the legislation are fulfilled. The FNDE promotes training to those involved in the process. In addition, it provides monitoring and answers any requests for clarification (BRASIL, 2009; TURPIN, 2009). With regard to purchases from family farming, Teo (2018) reinforces the fact that the government should replace the "buy the lowest price products" policy by the "buy the best price products" policy. These problems should be presented to Prefecture sectors such as the Legal section and Purchases/Biddings section. In many cases, these sections are opposed to replace the conventional bidding procedure by the public call (BACCARIN et al., 2017) which makes compliance with legislation difficult.

In order for the purchases and sales process to function properly, the various actors involved in this process have to be articulated. This is a fundamental factor previously mentioned by a number of authors (BACCARIN et al., 2017; SILVA; SOUSA, 2013; BRASIL, 2016a; SCHWARTZMAN et al., 2017; TRICHES; KILIAN, 2016). The articulation aims to identify the diversity and amount of food items available and that may be included in the menus which stresses the importance of dialogue and communication and the work as a team (BRASIL, 2016a). The nutritionist plays a major role in this process reinforcing the fulfillment of the complementary attribution described in the Resolution of the Federal Council of Nutritionists $n^{\circ}$ 465/2010 (CFN, 2010). This resolution establishes the interaction with family farmers with the goal of gaining knowledge on the local production of food items and introduction of these products in the school menus (CHAVES et al., 2013). In the Southern Region of Brazil, this interaction between the nutritionist and farmers was reported by $88.8 \%$ of the professionals in the study conducted by CORREA et al. (2017). Another highlight was the participation of members of the CAE which is very important since these individuals follow the entire process from the acquisition of the products to the acceptance of the food menus (BRASIL, 2016a).

Regarding the percentage of training of the individuals involved in the food acquisition process, the nutritionist and the CAE members were considered highly valuable professionals. It is expected that the nutritionist, precisely because he 
or she is the professional responsible for the PNAE, will seek continuous training in this area. Counselors should be properly trained to act as recommended by the legislation (BRASIL, 2009; BRASIL, 2013; BRASIL, 2016a). Food handlers, also with a high percentage of professionals, participate in all processes inside schools that involve food and that require regular training (FERNANDES et al., 2014; SILVA; SOUSA, 2013).

Regarding the challenges, obstacles and difficulties pointed out by the municipalities, it is worth mentioning that the survey was answered by the members of the municipalities' management. This might have limited the results to only one of the parties since no information was obtained from farmers. Other studies previously published elsewhere have also shown that the main reasons are related to the lack of preparation of the farmers, to the quality standard, and product and establishment records as these are not registered in Associations or Cooperatives or lack the training and technical assistance for largescale production (RIBEIRO et al., 2013; ROCHA et al., 2018; TOYOYOSHI et al., 2013; TRICHES; KILIAN, 2016). In these situations, it is necessary to identify producers, train them in order to meet the required quality requirements, assist and support them in preparing documentation, and establish attendance routines. Some municipalities believe that in order to overcome these difficulties, the creation of associations and cooperatives would make them more prepared to help the PNAE (RIBEIRO et al., 2013). In this context, the participation of Technical Assistance and Rural Extension agencies (ATER) should be reinforced and encouraged (BACCARIN et al., 2017) since these organs help improve production systems developing quality products demanded by the markets and organization of farmers for market access. One study has shown that during the last decade family farming has experienced continuous growth due to the creation of a local cooperation network and the interaction between several institutions. ATER stand out in this process (DE PAULA et al., 2014).

DE PAULA et al. (2014) presented a report of farmers that faced challenges in establishing productivity and experiencing difficulties such as low profitability which generates lack of interest and lack of enthusiasm, a feeling of exclusion, and also issues related to food and nutrition security.

In contrast, a study presented a report on municipalities describing the main reasons why these municipalities are obtaining good results when buying products of family farming, and cited city hall projects in partnership with SEBRAE, the joint effort between family farmers, and the Department/ Secretary of Education conducted by the nutritionist. Additional components involved in this process include the organization and cooperation between farmers, the support of representative entities that supports and train producers, and the participation of municipal councils (TOYOYOSHI et al., 2013). The present study corroborates these findings considering that it was observed that the involvement of these players such as nutritionists, the CAE and EMATER play important roles to increase the purchase of food products from family farming.

With respect to the replacement of products, it should be highlighted that there should be flexibility between the need for a product and the availability of delivery, and the dialogue between the parts involved should the basis of the negotiation (FERIGOLLO et al., 2017).

In the present study, the diversity of products acquired by the municipalities of Rio Grande do Sul, especially in natura or with low degree of processing, was obvious. A number of studies have reported these benefits in different regions of the country such as increased variability of products in the food menu, and greater supply of fresh products and food of better quality (BACCARIN et al., 2017; HOLZ; NETO, 2016). The large-scale existence of this type of product shows the effectiveness of the program and also demonstrates that the legislation assures nutritional improvement in school meals (BACCARIN et al., 2017).

The food items purchased by the municipalities were mostly vegetables, vegetables and fruits. Similar results are reported in previous studies published elsewhere by a number of researchers including TOYOYOSHI et al. (2013), GONÇALVES et al. (2015), and AMORIM et al. (2016). In this context, the Dietary Guidelines for the Brazilian Population focuses on the concept that the basis and foundation of nutrition should include food items from these groups. It also highlights the importance of consumption of fresh or processed foods as well as the consumption of regional foods to ensure food and nutrition security and adequate nutrition (BRASIL, 2014). These acquisitions also contribute to compliance with the PNAE legislation, i.e. the minimum supply of three portions of fruits and vegetables per week ( $200 \mathrm{~g} /$ student/week) in school meals (BRASIL, 2013) and, as a result, increased consumption of food items by students (BARONE et al., 2016; TRICHES; SCHNEIDER, 2010). In these groups, most of the municipalities acquired lettuce, cabbage and orange which corroborates 
with the findings published by FERIGOLLO et al. (2017).

It is worth mentioning that all these food items purchased by $91.6 \%$ of the municipalities were bought from local producers (of the same municipality) showing short supply chains. Studies showed that this system promotes an increase in socioeconomic factors through the creation of new jobs and development of the local market for food production which boost the economy (AGUIAR et al., 2018).

The potential for acquiring sociobiodiversity products should also be emphasized. Few municipalities purchase this type of product though. These food items are generally undervalued, neglected or underutilized and; therefore, deserve special attention. These products value regional production, recover habits and food cultures, strengthen traditional communities, and diversify food from the perspective of food and nutrition security (BRASIL, 2017). Thus, initiatives in the scope of public policies related to socio-biodiversity products and strengthening of the productive chains are fundamental. As an example, Interministerial Ordinance No. 163/2016 (BRASIL, 2016b) supports in natura commercialization or selling of products derived from socio-biodiversity within the scope of operations carried out by PNAE and other programs such as the Food Acquisition Program and may be used as the legal basis for such acquisition.

\section{CONCLUSION}

Most municipalities have met the requirement to allocate at least $30 \%$ of the resources coming from the FNDE for school meals to food items from family farming. However, a considerable number of municipalities do not meet such requirements.

The main challenges, obstacles or difficulties for the acquisition of family farming food items pointed out by the municipalities were that family farmers are, to some extent, poorly organized, or uninterested in providing food for the PNAE.

There was a great diversity of foods purchased, most of which in natura, especially vegetables, cereals, breads, pastas, and tubers; and fruits. This enables and facilitates the insertion of healthy foods in the menus and meals at schools. Regarding the socio-biodiversity products, there is a low percentage of municipalities that acquire them $(8 \%)$. Therefore, a greater incentive for such type of purchase is required.
Results of our study indicated the tendency of the municipalities in south Brazil to foment the local economy with incentive to the consumption and production of regional foods in agreement with the recommendations published in the Food Guide of the Brazilian Population and the legislation that regulates the PNAE. Despite the challenges faced, the municipalities of RS satisfactorily fulfill the role of linking family farming to school meals.

\section{ACKNOWLEDGMENTS}

The authors gratefully acknowledge the Fundo Nacional de Desenvolvimento da Educação (FNDE) and the Centro Colaborador em Alimentação e Nutrição do Escolar of Universidade Federal do Rio Grande do Sul (CECANE UFRGS) for the institutional support to carry out this study.

\section{BIOETHICS AND BIOSSECURITY COMMITTEE APPROVAL}

Research proposal approved by the Research Committee of the School of Medicine of the Universidade Federal do Rio Grande do Sul (UFRGS) (Protocol No. 27815).

\section{DECLARATION OF CONFLICTING INTERESTS}

The authors declare no conflict of interest. The founding sponsors had no role in the design of the study; in the collection, analyses, or interpretation of data; in the writing of the manuscript, and in the decision to publish the results.

\section{AUTHORS' CONTRIBUTIONS}

FCR, RSC and GCP conceived and designed the project; and participated in analysis and interpretation of data. FCR prepared the draft of the manuscript. FSH and CPMS participated in the systematization of data. LSM and ABAO participated in the project design and data analysis. All authors critically revised the manuscript and approved of the final version.

\section{REFERENCES}

AGUIAR, L. Da C. et al. Short food supply chain: characteristics of a family farm. Ciência Rural, v. 48, n. 5, p. 1-8, 2018. Available from: <http://www.scielo.br/pdf/cr/ v48n5/1678-4596-cr-48-05-e20170775.pdf $>$. Accessed: Dec. 3, 2018. doi: 10.1590/0103-8478cr20170775.

AMORIM, A. L. B. De. et al. Acquisition of family farm foods for school meals: Analysis of public procurements within rural family farming published by the cities of São Paulo state. Revista de Nutrição, v. 29, n. 2, p. 297-306, 2016. Available from: <http:// www.scielo.br/pdf/rn/v29n2/1415-5273-rn-29-02-00297.pdf $>$. Accessed: Dec. 3, 2018. doi: 10.1590/1678-98652016000200012.

BACCARIN, J. G. et al. Indicadores de avaliação das compras da agricultura familiar para alimentação escolar no Paraná, Santa Catarina e São Paulo. Revista de Economia e Sociologia Rural, v. 
55 , n. 1, p. 103-122, 2017. Available from: <http://www.scielo.br/ pdf/resr/v55n1/1806-9479-resr-55-01-00103.pdf $>$. Accessed: Dec. 3, 2018. doi: 10.1590/1234-56781806-94790550106.

BARONE, B. et al. Supply of fruits and vegetables family farming in the school feeding. Vigil. sanit. debate, v. 4, n. 3, p. 86-95, 2016. Available from: <https://visaemdebate.incqs.fiocruz.br/ index.php/visaemdebate/article/view/758/333>. Accessed: Dec. 3, 2018. doi: 10.22239/2317-269X.00758.

BELIK, W.; CHAIM, N. A. National school meal program and municipal administration: management efficiency, social participation and local development. Revista de Nutrição, v. 22, n. 5, p. 595-607, 2009. Available from: <http://www.scielo.br/pdf/ rn/v22n5/v22n5a01.pdf $>$. Accessed: Dec. 3, 2018. doi: 10.1590 S1415-52732009000500001.

BRASIL. MINISTERIO DA SAÚDE. Guia alimentar para a população brasileira. [S.1.]: [s.n.], 2014. Available from: <http:// portalarquivos2.saude.gov.br/images/pdf/2014/novembro/05/ Guia-Alimentar-para-a-pop-brasiliera-Miolo-PDF-Internet.pdf $>$. Accessed: Dec. 3, 2018.

BRASIL. MINISTÉRIO DO MEIO AMBIENTE. Arranjos produtivos locais: APLs de produtos da sociobiodiversidade. [S.1.]: [s.n.], 2017. Available from: <http://www.mma. gov.br/publicacoes/desenvolvimento-rural/category/75sociobiodiversidade.html?download=1534:arranjos-produtivoslocais-\%E2\%80\%93-apls-de-produtos-da-sociobiodiversidade> Accessed: Dec. 3, 2018

BRASIL. Lei no 11.326, de 24 de julho de 2006. Brasília: [s.n.]., 2006 Available from: <http://www.planalto.gov.br/ccivil_03/_Ato20042006/2006/Lei/L11326.htm>. Accessed: Dec. 3, 2018

BRASIL. Lei no 11.947, de 16 de junho de 2009. Available from: $<$ http://www.planalto.gov.br/ccivil_03/_Ato2007-2010/2009/Lei/ L11947.htm>. Accessed: Dec. 3, 2018 .

MINISTÉRIO DA EDUCAÇÃO. Resolução CD/FNDE no 26, de junho de 2013. Available from: <http://www.fnde.gov. $\mathrm{br} / \mathrm{acesso-a}$-informacao/institucional/legislacao/item/4620resolu $\% \mathrm{C} 3 \% \mathrm{~A} 7 \% \mathrm{C} 3 \% \mathrm{~A} 30-c d-f n d e-n \% \mathrm{C} 2 \% \mathrm{BA}-26$,-de-17-dejunho-de-2013>. Accessed: Dec. 3, 2018.

MINISTÉRIO DA EDUCAÇÃO. Resolução no 4, de 2 de abril de 2015. Available from: Available from: <http://www.mda.gov. br/sitemda/sites/sitemda/files/user_arquivos_383/https_ mail mda_.gov_.pdf >.Accessed: Jan 3, 2019.>. Accessed: Dec. 3, 2018.

MINISTÉRIO DA EDUCAÇÃO. Aquisição de produtos da agricultura familiar para a alimentação escolar 2a edição. 2016a. p. 60. Available from: <https://rebrae.com.br/wp-content/ uploads/2017/10/pnae manual aquisicao-de-produtos-daagricultura-familiar_2_ed.pdf $>$. Accessed: Dec. 3, 2018.

MINISTÉRIO DO MEIO AMBIENTE. Portaria Interministerial no 163, de 11 de maio de 2016b. Available from: <https:// alimentusconsultoria.com.br/portaria-interministerial-18-2016/>. Accessed: Dec. 3, 2018.

CHAVES, L. G. et al. Reflections on the activities of nutritionists on the Brazilian School Nutrition Program. Ciência \& Saúde Coletiva, v. 18, n. 4, p. 917-926, 2013. Available from: $<$ http:// www.scielo.br/pdf/csc/v18n4/03.pdf>. Accessed: Dec. 3, 2018. doi: $10.1590 / \mathrm{S} 1413-81232013000400003$.

CFN. CONSELHO FEDERAL DE NUTRICIONISTAS Resolução CFN no 465/2010. Available from: <https://www. legisweb.com.br/legislacao/?id=112812>. Accessed: Dec. 3, 2018.

CORRÊA, R. Da S. et al. The role of the nutritionist in the National School Food Program in the southern region of Brazil. Ciência \& Saúde Coletiva, v. 22, n. 2, p. 563-574, 2017. Available from: <http://www.scielo.br/pdf/csc/v22n2/1413-8123csc-22-02-0563.pdf $>$. Accessed: Dec. 3, 2018. doi: 10.1590/141381232017222.09622016 .

DE PAULA, M. M. et al. Institutional markets in family farming: difficulties and challenges. Revista de Política Agrícola, n. 1, p. 33-43, 2014. Available from: $<$ https://seer.sede.embrapa.br/index. php/RPA/article/view/883/808>. Accessed: Dec. 3, 2018.

FERIGOLLO, D. et al. Aquisição de produtos da Agricultura Familiar para a Alimentação Escolar em municípios do Rio Grande do Sul. Revista de Saúde Publica, v. 51, n. 6, p. 1-10, 2017. Available from: $<\mathrm{http} / / / \mathrm{www}$. scielo.br/pdf/rsp/v51/pt_0034-8910rsp-S1518-87872017051006648.pdf $>$. Accessed: Dec. 3, 2018. doi: $10.1590 / \mathrm{s} 1518-8787.2017051006648$.

FERNANDES, A. G. De S. et al. School meals as an area for education in health: the perception of school cooks in the municipality of Rio de Janeiro, Brazil. Ciência \& Saúde Coletiva, v. 19 , n. 1, p. 39-48, 2014. Available from: <http://www.scielo.br/ pdf/csc/v19n1/1413-8123-csc-19-01-00039.pdf $>$. Accessed: Dec. 3, 2018. doi: 10.1590/1413-81232014191.1711.

GONÇALVES, H. V. B. et al. Family farming products on menus in school feeding: a partnership for promoting healthy eating. Ciência Rural, v. 45, n. 12, p. 2267-2273, 2015. Available from: $<$ http://www. scielo.br/pdf/cr/v45n12/1678-4596-cr-0103 8478cr20150214.pdf>. Accessed: Dec. 3, 2018. doi: 10.1590/0103-8478cr20150214.

HOLZ, E.; NETO, E. Q. Evolution of the acquisition of family agriculture food provided to schoolchildren in the municipal network Medianeira-PR in the period 2012-2015. Revista Orbis Latina, v. 6, n. 1, p. 89-102, 2016. Available from: <https:// revistas.unila.edu.br/orbis/article/viewFile/532/487>. Accessed: Dec. 3, 2018.

IBGE. INSTITUTO BRASILEIRO DE GEOGRAFIA E ESTATÍSTICA. Censo Demográfico 2010. Características da População e dos Domicílios. Instituto Brasileiro de Geografia e Estatística, 2010. p. 1-270. Available from: <https://biblioteca. ibge.gov.br/visualizacao/periodicos/93/cd_2010_caracteristicas_ populacao_domicilios.pdf $>$. Accessed: Dec. 3, 2018.

MACHADO, L. D. S. et al. Organic and/or agro-ecological foods in school meals in municipalities in Rio Grande do Sul, Brazil. DEMETRA: Alimentação, Nutrição \& Saúde, v. 13, n. 1, p. 1-16, 2018. Available from: <https://www.e-publicacoes.uerj.br/ index.php/demetra/article/view/30699/24206>. Accessed: Dec. 3, 2018. doi: 10.12957/demetra.2018.30699.

PEDRAZA, D. F. et al. Evaluation of the National School Food Program: review of the literature. Ciência \& Saúde Coletiva, v. 23 , n. 5 , p. 1551-1560, 2018. Available from: <http:// www.scielo.br/pdf/csc/v23n5/1413-8123-csc-23-05-1551. 
pdf>. Accessed: Dec. 3, 2018. doi: 10.1590/141381232018235.17832016 .

RIBEIRO, A. L. De P. et al. Programa Nacional de Alimentação Escolar (PNAE) e a participação da agricultura familiar em municípios do Rio Grande do Sul. Revista Gestão e Desenvolvimento em Contexto, v. 1, n. 1, p. 37-40, 2013 Available from: $<$ http://revistaeletronica.unicruz.edu.br/index.php/ GEDECON/article/view/282/222>. Accessed: Dec. 3, 2018.

ROCHA, N. P. et al. Analysis of the national school feeding program in the municipality of Viçosa, state of Minas Gerais. Revista de Saúde Pública, v. 52, n. 16, p. 1-10, 2018. Available from: <http://www.rsp.fsp.usp.br/wp-content/uploads/articles xml/0034-8910-rsp-S1518-87872018052007090/0034-8910rsp-S1518-87872018052007090.x83745.pdf>. Accessed: Dec. 3, 2018. doi: 10.11606/S1518-8787.2018052007090.

SARAIVA, E. B. et al. Panorama of purchasing food products from family farmers for the Brazilian School Nutrition Program. Ciência \& Saúde Coletiva, v. 18, n. 4, p. 927-935, 2013. Available from: $<$ http://www.scielo.br/pdf/csc/v18n4/04.pdf > . Accessed: Dec. 3, 2018. doi: 10.1590/S1413-81232013000400004.

SCHWARTZMAN, F. et al. Background and elements of the linkage between the Brazilian school feeding program and family farming. Cadernos de Saúde Pública, v. 33, n. 12, p. 1-14, 2017. Available from: <http://www.scielo.br/pdf/csp/v33n12/en_16784464-csp-33-12-e00099816.pdf>. Accessed: Dec. 3, 2018. doi: 10.1590/0102-311x00099816.

SERENINI, M. J. Os desafios da escola pública paranaense na perspectiva do professor PDE. 2015. Available from: <http:// www.diaadiaeducacao.pr.gov.br/portals/cadernospde/pdebusca/ producoes pde>. Accessed: Dec. 3, 2018

LVA, A. P. F. Da; SOUSA, A. A. De. Organic foods from family farms in the National School Food Program in the State of Santa Catarina, Brazil. Revista de Nutrição, v. 26, n. 6, p. 701-714, 2013. Available from: <http://www.scielo.br/pdf/rn/v26n6/09.pdf> Accessed: Dec. 3, 2018. doi: 10.1590/S1415-52732013000600009.

SOARES, F. V. et al. Structured demand and smallholder farmers in Brazil: The case of PAA and PNAE. [S.1.]: [s.n.], 2013. Available from: <http://www.ipc-undp.org/pub/ IPCTechnicalPaper7.pdf>. Accessed: Dec. 3, 2018.

TEO, C. R. P. A. The partnership between the Brazilian School Feeding Program and family farming: A way for reducing ultra- processed foods in school meals. Public Health Nutrition, v. 21, n. 1, p. 230-237, 2018. Available from: <https:// www.cambridge.org/core/services/aop-cambridge-core/ content/view/F163E09CDDFD2D8D2D6BFAA1601564B2/ S $1368980017002117 \mathrm{a} . \mathrm{pdf} / \mathrm{partnership \_ between}$ the_brazilian_school_feeding_program_and_family farming a way for reducing ultraprocessed foods in school_meals.pdf $>$. Accessed: Dec. 3, 2018. doi: 10.1017) S1368980017002117.

MONTEIRO, C. A. Legal framework of the National School Feeding Program: a new reading for aligning purposes and practices in food acquisition. Revista de Nutrição, v. 25, n. 5, p. 657-668, 2012. Available from: <http://www.scielo.br/pdf/rn/ v25n5/a10.pdf $>$. Accessed: Dec. 3, 2018. doi: 10.1590/S141552732012000500010

TOYOYOSHI, J. Y. et al. Evaluation of the acquisition of food items from family farming for school meals. O Mundo da Saúde, v. 37, n. 3, p. 329-335, 2013. Available from: <http://www. revistamundodasaude.com.br/assets/artigos/2013/106/1829. pdf $>$. Accessed: Dec. 3, 2018. doi: 10.15343/01047809.2013373329335 .

TRICHES, R. M.; KILIAN, L. Social actors role in the purchase of family farming products for school feeding in Paraná counties. Redes (St. Cruz Sul, Online), v. 21, n. 3, p. 159-179, 2016. Available from: <https://online.unisc.br/seer/index.php/redes/ article/download/7055/pdf $>$. Accessed: Dec. 3, 2018. doi: 10.17058/redes.v21i3.7055

TRICHES, R. M.; SCHNEIDER, S. School Feeding and Family Farming: reconnecting consumption to production. Saúde e Sociedade, v. 19, n. 4, p. 933-945, 2010. Available from: <http:// www.scielo.br/pdf/sausoc/v19n4/19.pdf>. Accessed: Dec. 3, 2018. doi: 10.1590/S0104-12902010000400019.

TURPIN, M.E. Aalimentação escolar como fator de desenvolvimento local por meio do Apoio aos agricultores familiares. Segurança Alimentar e Nutricional, v. 16, n. 2, p. 20-42, 2009. Available from: <https://periodicos.sbu.unicamp.br/ojs/index.php/san/article/ view/8634783/2702>. Accessed: Dec. 3, 2018.

WORLD FOOD PROGRAMME. State of School Feeding Worldwide 2013. World Food Programme, 2013. p. 1-144. Available from: <https://documents.wfp. org/stellent/groups/public/documents/communications/ wfp257481.pdf? ga=2.209634388.730459014.1546544837163442345.1546544837>. Accessed: Dec. 3, 2018. 